\title{
OKSIDASI LEMAK DALAM DAGING KELINCI DAN AYAM PADA KONDISI PENYIMPANAN YANG BERBEDA
}

\author{
Purbowatiningrum, Damin Sumardjo, Wuryanti, Nies Suci Mulyani \\ Laboratorium Biokimia Jurusan Kimia F MIPA, Universitas Diponegoro
}

\begin{abstract}
ABSTRAK
Ketengikan akibat oksidasi merupakan masalah yang serius pada daging selama penyimpanan. Telah dilakukan penelitian untuk mengukur tingkat oksidasi pada daging kelinci dan ayam selama 1 sampai 9 hari penyimpanan dengan angka TBA sebagai parameter. Aldehid hasil oksidasi dari lemak akan membentuk kompleks berwarna dengan TBA yang intensitas warnanya diukur dengan UV -Vis pada panjang gelombang $450 \mathrm{~nm}$ untuk daging ayam dan $447 \mathrm{~nm}$ untuk daging kelinci. Kondisi penyimpanan dilakukan dengan pembungkus plastik dan pembungkus kedap udara pada suhu $4^{\circ} \mathrm{C}$ terhadap daging cacah dan utuh. Pada daging kelinci dengan pembungkus plastik dan pembungkus kedap udara baik cacah maupun utuh memiliki angka TBA yang lebih tinggi dibandingkan daging ayam. Namun daging kelinci dan ayam mengalami penurunan angka TBA dengan menggunakan pembungkus kedap udara.Dari hasil eksperimen diperoleh lemak total daging kelinci $2,949 \%$ dan daging ayam $7,2902 \%$. Sedangkan daging kelinci memiliki lebih banyak asam lemak tak jenuh dibandingkan daging ayam. Semakin lama penyimpanan oksidasi lemak yang terjadi semakin besar. Tetapi dapat dihambat dengan menggunakan pembungkus kedap udara.
\end{abstract}

Kata kunci : oksidasi, angka TBA, asam lemak tak jenuh

\section{ABSTRACT}

\section{Lipid Oxidation in Rabbit and Chicken Meat In Different Storage Condition}

Rancidity of meat that caused by oxidation is a serious problem in meat for a long storage. It have been done research to measure an extent of meat oxidation on rabbit and chicken for 1 up to 9 days storage using TBA value as a parameter. Aldehide as an oxidation yield of lipid in meat would form a colourful complex with TBA (2-Thiobarbiturat Acid) and intensity of the colour was able to be measured by UV - Vis spectrophotometer at $450 \mathrm{~nm}$ in chicken meat and $447 \mathrm{~nm}$ in rabbit meat. Storage was done by plastic wrapped and vacuum packaged atn $4 \mathrm{C}$ in minced and intact meat. By plastic wrapped and vacuum packaged condition both minced and intact, rabbit meat had higher TBA value than the chicken one. Otherwise, TBA value on rabbit and chicken meat would decrease by vacuum packaged. From the research, it is obtain that total lipid on rabbit is $2,949 \%$ and chicken one is $7,2909 \%$. Which those of rabbit meat has more unsaturated fatty acid than the chicken one. The longer the storage, the higher is the oxidation extent of lipid in meat but lipid oxidation in meat able to be retarded by vacuum packaged.

Keyword : oxidation, TBA value, unsaturated fatty acid 


\section{PENDAHULUAN}

Sumber lemak dapat diperoleh dari lemak hewani maupun lemak tumbuhan. Salah satu sumber lemak hewani adalah daging ayam dan daging kelinci. Karena pada da-ging ayam dan kelinci banyak mengan-dung asam lemak tak jenuh, maka daging akan mudah mengalami oksidasi selama penyimpanan. Oksidasi pada lemak mun-cul sebagai akibat dari reaksi antara oksi-gen di atmosfer dengan asam lemak tak jenuh yang terdapat dalam daging. ${ }^{(1)}$

Untuk itu dilakukan analisis tingkat oksidasi pada daging kelinci yang hasilnya di-bandingkan dengan tingkat oksidasi pada daging ayam, dengan menggunakan tes angka TBA (asam tibarbiturat). Daging di-lakukan dengan pembungkus dan keadaan penyimpanan yang berbeda. Yaitu dike-mas dengan pembungkus plastik dan ke-masan hampa terhadap daging utuh dan cacah yang disimpan pada suhu $4^{\circ} \mathrm{C}$. Le-mak yang teroksidasi akan menghasilkan malonaldehid, kemudian bereaksi dengan asam tiobarbiturat dan menghasilkan war-na merah. Intensitas warna yang dihasil-kan menunjukan tingkat oksidasi. Perbe-daan intensitas warna yang dihasilkan di-ukur dengan spektrofotometer UV-Vis. ${ }^{(2)}$ Oksidasi biasanya dimulai dengan pembentukan peroksida dan hidroperoksida. Tingkat selanjutnya adalah terurainya asam lemak disertai dengan perubahan hidroperoksida menjadi keton dan aldehid, serta asam lemak bebas. ${ }^{(3)}$ Ketengikan terbentuk oleh adanya aldehid bukan oleh peroksida. Metode penentuan angka
TBA diperkenalkan oleh Bertheim untuk mengukur hasil oksidasi asam lemak tak jenuh. Warna merah yang terbentuk dari hasil oksidasi lemak dengan asam 2-tiobarbiturat. Oleh Patton dan Kurtz disimpulkan bahwa senyawa ini adalah senyawa malonaldehid yang jika direaksikan dengan senyawa TBA membentuk kompleks aldehid-TBA berwarna yang memiliki absorbansi pada panjang gelombang maksimum $532 \mathrm{~nm}^{(4)}$

Menurut Sudarmadji ${ }^{(5)}$, angka TBA adalah jumlah miligram malonaldehid yang terbentuk dari satu kilogram lemak. Dengan perhitungan angka TBA sebagai berikut:

Angka $T B A=7.8$ dengan $A$ adalah absorbansi maksimum, sedangkam 7,8 merupa-kam konstanta yang diperoleh Tarladgis.

\section{METODOLOGI}

Alat : magnetik stirer merk Nuova dan Spinbar, seperangkat alat soklet, sentrifuge model 228, spektrometer UVVis merk Shimadzu

Bahan : asam asetat glasial, asam tiobarbiturat, trikloroaseat, petroleum eter.

Cara kerja : sebagian daging dibiarkan utuh dan disimpan selama 0-9 hari dengan pembungkus plastik dan kemasan hampa pada suhu $4^{\circ} \mathrm{C}$, sebagian dicacah dengan perlakuan penyimpanan sama.

\section{Penentuan angka TBA}

Gelas beker $50 \mathrm{~mL}$ diisi daging 10 gram dan $20 \mathrm{~mL}$ akuades selanjutnya distirer selama 15 menit ditambah $20 \mathrm{~mL}$ TCA $10 \%$ kemudian disentrifuse selama 10 menit. Disaring dengan kertas Wattman 
no. 42 dan dicuci dengan akuades. Lima mililiter sampel ditambah dengan $5 \mathrm{~mL}$ larutan TBA $0,75 \%$ kemudian diamkan dalam waterbath pada suhu $50^{\circ} \mathrm{C}$ selama 30 menit dan didinginkan 10 menit dalam air es. Selanjutnya diukur panjang gelom-bang optimum.

\section{Penentuan kadar lemak;}

Empat puluh lima gram daging yang dihaluskan dimasukkan dalam timble, dilakukan ekstraksi soklet dengan petroleum eter selama 4 jam pertama dan 2 jam beri kutnya dengan petroleum eter yang baru.

\section{HASIL DAN PEMBAHASAN}

Tabel 1: Hasil perhitungan angka TBA pada daging dengan pembungkus plastik pada suhu $4^{\circ} \mathrm{C}$.

\begin{tabular}{|c|c|c|c|c|}
\hline $\begin{array}{c}\text { Lama } \\
\begin{array}{c}\text { Penyimpanan } \\
\text { (hari) }\end{array}\end{array}$ & $\begin{array}{c}\text { Daging } \\
\text { Kelinci Cacah }\end{array}$ & $\begin{array}{c}\text { Daging } \\
\text { Kelinci Utuh }\end{array}$ & $\begin{array}{c}\text { Daging Ayam } \\
\text { Cacah }\end{array}$ & $\begin{array}{c}\text { Daging Ayam } \\
\text { Utuh }\end{array}$ \\
\hline 0 & 0,0624 & 0,0624 & 0,0390 & 0,0390 \\
1 & 0,4879 & 0,4324 & 0,3354 & 0,2704 \\
2 & 0,9377 & 0,7843 & 0,6015 & 0,4844 \\
3 & 1,5172 & 1,5945 & 0,9455 & 0,7835 \\
4 & 2,4153 & 2,1693 & 1,3962 & 1,1059 \\
5 & 2,7768 & 2,5705 & 1,9413 & 1,5505 \\
6 & 3,7093 & 3,1676 & 2,2447 & 1,7819 \\
7 & 5,3273 & 4,6852 & 2,8636 & 2,6676 \\
8 & 7,5253 & 7,0009 & 4,8620 & 4,4269 \\
9 & 8,7724 & 8,6051 & 6,8839 & 6,3986 \\
\hline
\end{tabular}

Tabel 2: Hasil perhitungan angka TBA pada sampel dengna pembungkus kedap udara disimpan pada suhu $4^{\circ} \mathrm{C}$.

\begin{tabular}{|c|c|c|c|c|}
\hline $\begin{array}{c}\text { Lama } \\
\begin{array}{c}\text { Penyimpanan } \\
\text { (hari) }\end{array}\end{array}$ & $\begin{array}{c}\text { Daging } \\
\text { Kelinci Cacah }\end{array}$ & $\begin{array}{c}\text { Daging } \\
\text { Kelinci Utuh }\end{array}$ & $\begin{array}{c}\text { Daging Ayam } \\
\text { Cacah }\end{array}$ & $\begin{array}{c}\text { Daging Ayam } \\
\text { Utuh }\end{array}$ \\
\hline 0 & 0,0624 & 0,0624 & 0,0390 & 0,0390 \\
1 & 0,0754 & 0,0650 & 0,0554 & 0,0494 \\
2 & 0,1273 & 0,1078 & 0,0650 & 0,0676 \\
3 & 0,1403 & 0,1161 & 0,0919 & 0,0793 \\
4 & 0,1828 & 0,1335 & 0,1153 & 0,1049 \\
5 & 0,2158 & 0,1664 & 0,1595 & 0,1230 \\
6 & 0,2763 & 0,2147 & 0,1525 & 0,1569 \\
7 & 0,4152 & 0,3085 & 0,2756 & 0,2570 \\
8 & 0,5018 & 0,3779 & 0,3276 & 0,2842 \\
9 & 0,6344 & 0,5443 & 0,4187 & 0,3917 \\
\hline
\end{tabular}


Oksidasi lemak menghasilkan senyawasenyawa yang berbau tidak enak/tengik terutama dari golongan aldehid. Secara umum aldehid merupakan produk sekunder dari lemak setelah terbentuk peroksi$\mathrm{da}^{(6)}$ Aldehid hasil oksidasi lemak pada 'daging bereaksi dengan TBA membentuk senyawa komplek berwarna ${ }^{(7)}$ Hasil pengukuran absorbansi pada panjang gelom-bang $450 \mathrm{~nm}$ untuk daging ayam dan $447 \mathrm{~nm}$ untuk daging kelinci.

Dan sesuai yang dilaporkan oleh Mercuse dan Johansson ditemukan dua pigmen un-tuk analisis angka TBA yaitu pigmen me-rah pada panjang gelombang $530 \mathrm{~nm}$ dan pigmen kuning pada panjang gelombang $450 \mathrm{~nm}$. Yang berarti klas aldehid yang terkandung dalam daging ayam maupun daging kelinci adalah pigmen kuning.

Pada tabel perhitungan angka TBA pada daging dengan pembungkus plastik, dapat dilihat bahwa daging kelinci mempunyai angka TBA lebih tinggi dibandingkan ang-ka TBA pada daging ayam. Hal ini me-nunjukkkan bahwa daging kelinci mempu-nyai asam lemak tak jenuh dibanding da-ging ayam. Karena oksidasi menyerang ikatan rangkap dari asam lemak tak jenuh. Fenomena seperti ini juga dapat dilihat pa-da hasil perhitungan angka TBA daging dengan pembungkus kemasan hampa.

Sedangkan angka TBA lebih tinggi terdapat pada daging yang dicacah baik pada pembungkus plastik maupun pada kemasan hampa. Dengan angka TBA yang makin tinggi menunjukkan malonaldehid yang dihasilkan semakin banyak, berarti tingkat oksidasi dari daging makin tinggi pula. Serta mengalami kenaikan dengan semakin lamanya waktu penyimpanan.

Pada perhitungan angka TBA dengan kemasan hampa mempunyai angka TBA lebih rendah dari angka TBA daging dengan pembungkus plastik. Karena kontak dengan udara dapat dikurangi, sehingga oksidasi pada asam lemak tak jenuh dapat dihambat.

Dari hasil ekstraksi lemak pada daging ke-linci adalah 2,949\% dan daging ayam $7,2909 \%$. Berarti kandungan lemak total dalam daging kelinci lebih rendah dibanding daging ayam. Sedangkan dari hasil perhitungan angka TBA daging kelinci mempunyai angka TBA yang lebih tinggi dibanding daging ayam. Hal ini menunjukkan daging kelinci mempuyai kandungan asam lemak tak jenuh yang lebih banyak dibanding daging ayam. Karena malonaldehid bereaksi dengan TBQ merupakan hasil oksidasi sekunder dari asam lemak tak jenuh.

\section{KESIMPULAN}

Daging kelinci mempunyai kandungan asam lemak tak jenuh lebih banyak dari daging ayam sehingga baik untuk konsumsi diet. Penyimpanan daging dalam keadaan utuh lebih efektif dibanding dalam keadaan cacah, dengan menggunakan kemasan hampa dapat menghambat oksidasi lemak dalam daging selama penyimpanan. 


\section{DAFTAR PUSTAKA}

1. Espla, Fernandez dan O'neill,E, 1993, Journal of Food Science, Vol.56, 1262-1264.

2. Anonim, 1995, Lemak dan Dampaknya Bagi Kesehatan, Majalah Intisari edisi November 1995, 68-69.

3. Gunstone,FD, 1967An Introduction to The Chemistryand Biochemistry of Fatty Acid and Their Glycerides, Chapman and Hall LTD, 11 New Fetter Lane ECA, Great Britain, 105, 112-114.

4. Gray,J, and Pearson,AM, 1987, Rancidity and Warmed Over Flavor, in Advances in Meat Reseach, vol 3, Departement of Food Science and
Human Nutrient, Michigan State University East Lansing, Michigan , An Avi Book Published by Van Nostrand Reinhold Company, New York, 221-251.

5. Sudarmadji,Slamet, 1989, Analisa Bahan Makanan dan Pertanian, Edisi ketiga, Penerbit Liberty, Yokyakarta,59-70.

6. Ketaren, 1966, Lemak dan Minyak, Penerbit UI press, Jakarta, 2-29.

7. Pomeranz,Y,Cliffton,E, 1990, Food Analysis, Theory and Practise, second edition, An Avi Book pblished by Van Nostrand Reinhold Company, New York,735-737. 